\title{
Perancangan Aplikasi Penentuan Dosis Pemupukan Kelapa Sawit Menggunakan Metode SAW Berbasis Android
}

\author{
Fitri Ayu ${ }^{1}$, Ari Mustofa ${ }^{2}$ \\ Program Studi Manajemen Informatika, AMIK Mahaputra Riau 1,2 \\ fitriayu@amikmahaputra.ac.id ${ }^{1}$, arytafa@gmail.com ${ }^{2}$
}

\begin{tabular}{l} 
Article Info \\
\hline History: \\
Dikirim 19 Agustus 2020 \\
Direvisi 06 Oktober 2020 \\
Diterima 04 November 2020 \\
\hline
\end{tabular}

Kata Kunci :

Android

Kelapa Sawit

Pemupukan

SAW

SPK

\begin{abstract}
Abstrak
Pemupukan merupakan salah satu syarat pemeliharaan tanaman termasuk pada tanaman kelapa sawit yang selama ini menjadi penghasil bahan baku utama untuk produksi minyak sawit. Namun sering terjadi persoalan-persoalan yang dialami para petani saat proses pemupukan seperti jenis pupuk yang tidak tepat dan dosis pupuk yang tidak sesuai dengan kebutuhan dilapangan sehingga para petani mendapatkan hasil panen yang tidak sebanding dengan jumlah biaya yang telah dikeluarkan untuk penggunaan pupuk. untuk mengatasi persoalan mengenai penentuan jumlah dosis pupuk diterapkan metode simple additive weightig (SAW) yang diimplementasikan dalam sistem pengambilan keputusan dalam menentukan dosis pemupukan pada tanaman kelapa sawit dengan menggunakan pupuk organik cair (POC) NASA. Proses pengolahan data yang telah didapat dari hasil pengujian sampel laboratorium oleh asosiasi Sawitku Masa Depanku (SAMADE) dianalisa dengan metode SAW untuk menentukan alternatif terbaik yang akan dijadikan sebagai acuan pada proses perhitungan terhadap rekomendasi dosis pupuk dengan cara membandingkan hasil konversi nilai setiap kriteria pada alternatif terpilih. Dari penelitian yang dilakukan dan telah diimplementasikan kedalam aplikasi yang dibangun serta penilaian kuisioner dari sampel 90 orang petani yang tergabung dalam kelompok tani agro lestari, terhadap sistem yang di buat, di dapat tingkat kepuasan user sebesar $82,4 \%$ jadi aplikasi yang dibangun berbasis android dapat memberikan hasil yang sangat baik dalam memberikan rekomendasi jumlah dosis pupuk POC NASA yang tepat terhadap tanaman kelapa sawit.
\end{abstract}

(C) This work is licensed under a Creative Commons AttributionShareAlike 4.0 International License.

\section{Koresponden:}

Fitri Ayu

Program Studi Manajemen Informatika

AMIK Mahaputra Riau

Jln. HR. Soebrantas No. 77, Pekanbaru, Indonesia, 28294

Email : fitriayu@amikmahaputra.ac.id

\section{PENDAHULUAN}

Tanaman Kelapa sawit (Elaeis guineensis Jacq) merupakan komoditas perkebunan andalan Indonesia khususnya Provinsi Riau, Tanaman ini memiliki prospek yang sangat baik untuk dikembangkan sebagai sumber perolehan devisa negara. Kelapa sawit menghasilkan minyak nabati terbesar di Indonesia, yaitu per hektar 5-7 kali lebih besar dibandingkan dengan tanaman penghasil minyak lainnya [1]. Oleh karena itu, tanaman kelapa sawit menjadi salah satu tanaman penting 
penghasil minyak di dunia dan dibudidayakan secara luas di Asia tenggara termasuk Malaysia, Indonesia, dan Thailand [2].

Kelapa sawit umumnya dibudidayakan pada tanah tropik yang memiliki tingkat kesuburan kimia rendah dan kesuburan fisik yang beragam [3]. Secara umum produktivitas tanaman kelapa sawit dipengaruhi oleh faktor lingkungan, genetik dan teknik budidaya [4]. Pemupukan merupakan faktor utama untuk mengatasi kondisi tanah yang marjinal khususnya dalam hal kesuburan tanah, sehingga dibutuhkan keseimbangan dosis dan jenis pupuk yang digunakan [5]. Pemupukan dengan dosis yang tepat dan jadwal yang teratur akan mempercepat produktivitas tanaman kelapa sawit. Pemberian pupuk dimaksudkan untuk memenuhi kebutuhan hara yang tidak dapat disediakan oleh tanah, Pupuk Organik Cair (POC) NASA merupakan unsur-unsur hara makro yang berperan penting dalam pertumbuhan tanaman kelapa sawit. Pupuk ini terbuat dari bahan-bahan organik yang diproduksi oleh PT.Natural Nusantara (NASA) yang dirancang secara khusus terutama untuk mencukupi kebutuhan nutrisi lengkap tanaman [6].

Pada penelitian ini, peneliti mencoba melakukan pengamatan langsung pada perkebunan kelapa sawit masyarakat yang tergabung dalam kelompok tani Agro Lestari yang mana kelompok tani ini masih melakukan cara manual baik dalam pemberian pupuk maupun penentuan jumlah dosis pupuk yang akan diaplikasikan ke tanaman kelapa sawit tanpa adanya pemanfaatan teknologi dan perhitungan yang jelas. Sehingga terjadi ketidak seimbangan antara pemakaian pupuk dengan hasil yang diperoleh petani.

Dari pengamatan tersebut, peneliti mencoba merancang sebuah Aplikasi Penentuan Dosis Pemupukan Kelapa Sawit Menggunakan Metoda SAW Berbasis Android yang merupakan bagian dari sistem informasi berbasis komputer (termasuk sistem berbasis pengetahuan) yang melakukan pendekatan untuk menghasilkan berbagai alternatif keputusan untuk membantu pihak tertentu dalam menangani permasalahan dengan menggunakan data dan model, sehingga dapat digunakan untuk mendukung pengambilan keputusan pemberian dosis pemupukan yang tepat untuk tanaman kelapa sawit [7].

Dalam sistem yang akan dirancang, peneliti mencoba menerapkan metode Simple Additive Weighting (SAW) yang merupakan salah satu teknik MADM yang paling banyak digunakan untuk menghitung nilai akhir alternatif. Dalam teknik SAW, skor akhir masing-masing alternatif dihitung beserta peringkatnya [8].

Sehingga Aplikasi yang dirancang diyakini dapat menangani permasalahan pada kelompok tani Agro Lestari karena di implementasikan dalam bentuk sebuah Aplikasi Berbasis Mobile yang dapat membantu memberikan rekomendasi dosis pemupukan dengan (POC) NASA yang tepat untuk tanaman kelapa sawit yang dapat digunakan secara mudah dan praktis oleh para petani kapanpun dan dimanapun.

Penelitian lain yang pernah dilakukan yaitu tentang "Pemupukan dan Penentuan Dosis Pupuk Spesifikasi Lokasi Pada Plasma Perkebunan Kelapa Sawit di Perkebunan PT Unit PTPN Perkebunan XIV Luwu Timur (Burau)" yang dilakukan oleh A.Reski Amelia Hidayah (2017), dari penelitian ini dapat diketahui dosis pemupukan yang dilakukan oleh perkebunan inti dan perkebunan plasma telah sesuai dengan rekomendasi kebutuhan hara spesifik lokasi [9].

\section{METODE PENELITIAN}

Adapun tahapan kegiatan yang dilakukan menuju penyelesaian sistem dalam penelitian ini, mengikuti metode pengembangan sistem klasik, seperti terlihat pada gambar 1 berikut:

a. Requirement (Kebutuhan Sistem)

Sistem yang dibangun ini bertujuan untuk mengatasi masalah user atau petani dalam menentukan dosis pemupukan melalui penggunaan Aplikasi Penentuan Dosis Pemupukan Kelapa Sawit Menggunakan Metode SAW Berbasis Android. Android dimulai dari mengumpulkan data yang digunakan, yaitu data dari pengujian sampel kebun sawit masyarakat yang diteliti oleh asosiasi sawitku masa depanku (SAMADE) dan melakukan interview terhadap petani sawit serta studi kepustakaan untuk mendapat referensi penunjang untuk proses selanjutnya yaitu menganalisa kebutuhan sistem, memahami teknik yang akan 
digunakan dalam pengolahan data yang telah diperoleh dari tahapan requirement dan menganalisa apa saja yang akan digunakan baik hardware maupun software dalam membangun aplikasi android.

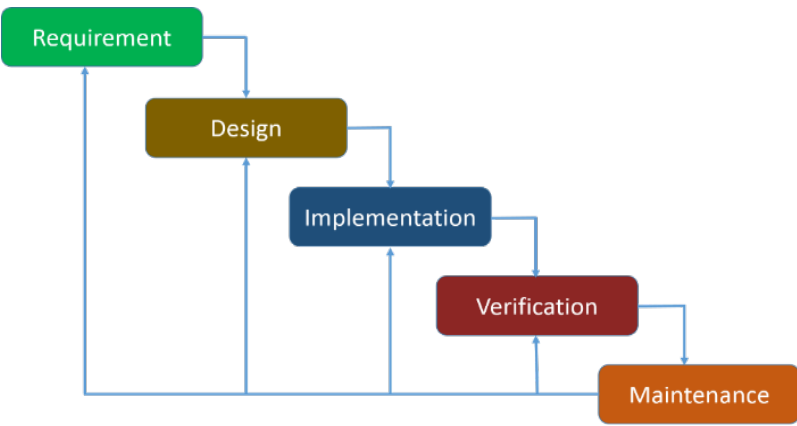

Gambar 1. Metode Penelitian

b. Design Sistem

Sistem Aplikasi rekomendasi penentuan pemupukan berbasis android dirancang sebagai aplikasi berbasis client server yang mana database berada pada komputer server sementara aplikasi absensi diinstal pada masing-masing perangkat mobile dari pengguna dan bertindak sebagai client yang berfungsi untuk menginput data sampel uji, selanjutnya data sampel uji diolah dengan menggunakan metode SAW untuk mendapatkan hasil rekomendasi pemupukan. Kemampuan metode SAW untuk melakukan penilaian secara lebih tepat karena di dasarkan pada nilai kriteria dan bobot preferensi yang sudah ditentukan, merupakan alasan pemilihan metode ini dalam penelitian. Untuk mengelola data pendukung dalam menentukan rekomendasi pemupukan kelapa sawit diperlukan sebuah aplikasi berbasis desktop yang digunakan sebagai pusat untuk mengatur data pendukung yang akan digunakan untuk proses penentuan rekomendasi pemupukan, seperti terlihat pada gambar 2.

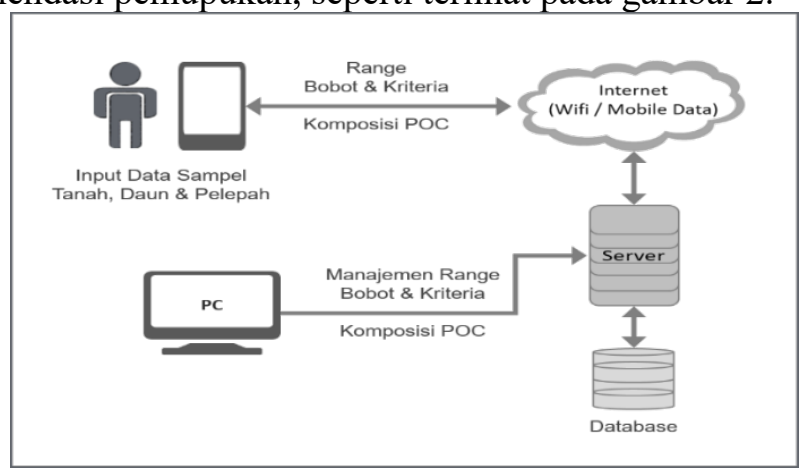

Gambar 2. Design system

c. ERD (Entity Relationship Diagram)

Entity Relationship Diagram digunakan untuk memodelkan struktur data serta hubungan antar data, untuk dapat menggambarkannya digunakan beberapa notasi serta simbol[10]. Database berperan sangat penting dalam sistem penentuan dosis pemupukan, untuk menyimpan informasi yang dibutuhkan. Dalam database terdiri dari sejumlah tabel yang digunakan untuk menyimpan berbagai kelompok data yang diperlukan untuk mengelola data rekomendasi pemupukan, pada dasarnya ada beberapa tabel khusus seperti data kebun, data sampel, alternatif, data bobot kriteria, normalisasi dan perangkingan seperti terlihat pada gambar 3. 


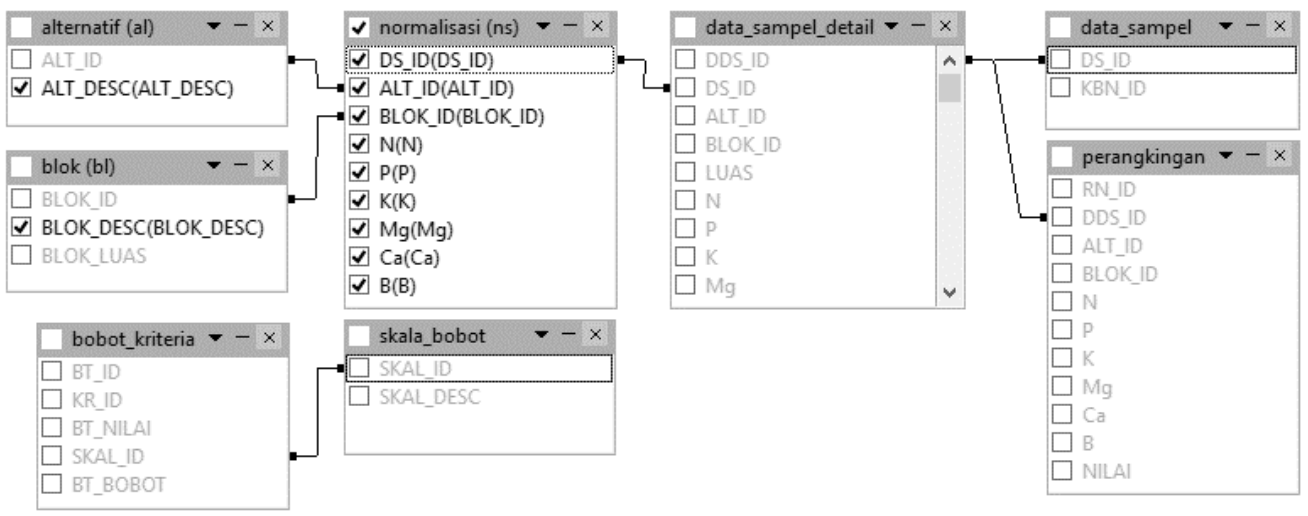

d. Implementasi

\section{Gambar 3. Entity Relationship Diagram}

Sistem aplikasi penentuan dosis pemupukan diimplementasikan untuk proses rekomendasi pemupukan, diawali dengan user menginstal aplikasi berbasis android melalui file apk, selanjutnya user melakukan login untuk masuk kemenu aplikasi. Setelah login berhasil aplikasi akan menampilkan menu data sampel. Untuk proses penentuan rekomendasi pupuk dilakukan dengan cara menginput data sampel yang sebelumnya sudah di rekapitulasi. Selama proses aplikasi melakukan pengecekan terhadap data sampel dan menentukan kriteria dan alternatif. Setelah pengecekan berhasil maka aplikasi akan membuat rating kecocokan pada setiap kriteria dan alternative. Aplikasi akan membuat list Perangkingan penjumlahan dari perkalian matriks ternormalisasi (R) dengan vektor bobot sehingga diperoleh nilai terbesar yang dipilih menjadi alternatif terbaik (A) sebagai referensi acuan yang akan digunakan dalam proses penentuan dosis pupuk. Selanjutnya aplikasi melakukan proses perhitungan perbandingan terhadap alternatif terpilih yang akan menghasilkan sebuah rekomendasi dosis pupuk POC pada tanaman kelapa sawit. seperti terlihat pada gambar 4 dan gambar 5.

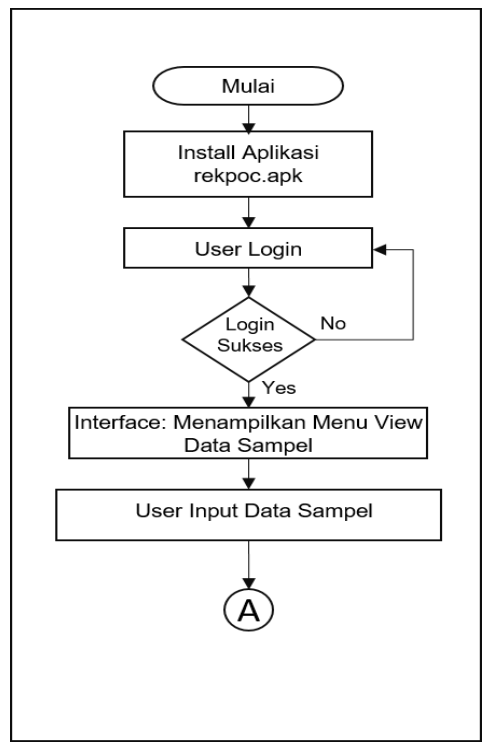

Gambar 4. User mempersiapkan aplikasi

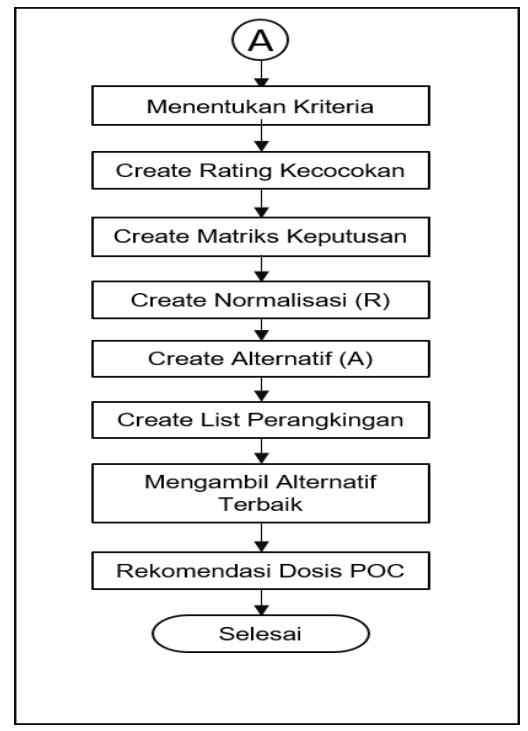

Gambar 5. Proses Rekomendasi Pemupukan 
e. Verifikasi

Pada tahap ini dilakukan proses pengujian terhadap hasil analisa menggunakan metode Simple Additive Weighting (SAW) yang sudah disematkan kedalam aplikasi yang dirancang untuk membantu dalam pengolahan data yang bertujuan untuk mengetahui apakah sudah sesuai dengan tujuan yang diharapkan, dimulai dengan memilih data kebun yang sudah diinput kedalam database, selanjutnya aplikasi akan melakukan perhitungan dengan tahapan SAW yang sudah diatur dalam aplikasi dan hasil akhir akan menampilkan data rekomendasi dosis pemupukan yang tepat yang harus digunakan oleh petani untuk tanaman sawit mereka.

f. Pemeliharaan Sistem

Sistem Aplikasi yang sudah dibangun, perlu dilakukan maintenance untuk menghindari masalah yang kemungkinan sewaktu-waktu bisa terjadi yang dapat menghambat penggunaan Aplikasi sewaktu digunakan oleh user atau para petani, meng-upgrate perubahan baik data ataupun faktor lingkungan yang terjadi, selain itu pemeliharaan sistem juga perlu dilakukan untuk meningkan kehandalan dari system yang telah dibangun.

Untuk menentukan rekomendasi Dosis Pupuk Organik Cair (POC) NASA terhadap tanaman kelapa sawit dengan metode Simple Additive Weighting (SAW) dapat dilihat pada gambar 6 berikut.

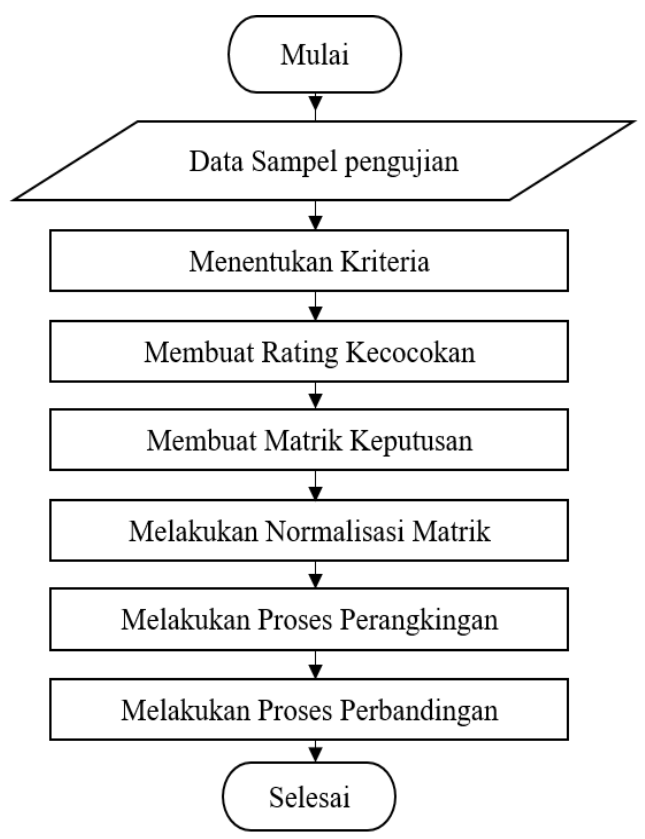

Gambar 6. Tahapan Menentukan Rekomendasi POC NASA

Tahapan Metode Simple Additive Weighting (SAW)

1. Mempersiapkan Data Pengujian

Data sampel pengujian didapat dari hasil uji lab yang dilakukan oleh Asosiasi Samade, yaitu data sampel uji dari Daun, Pelepah dan Tanah dengan lokasi pengambilan sampel pada bagian Depan, tengah dan Belakang.

2. Menentukan Kriteria (C)

Berdasarkan data sampel yang ada, kriteria yang akan digunakan terdiri dari Natrium(N),

Fosfor (F), Kalium(K), Magnesium(Mg), Kalsium(Ca) dan Boron(B). Alternatif yang digunakan dalam pengambilan keputusan terdiri dari Daun, Pelepah dan Tanah yang masing-masing diambil dari Areal Bagian Depan, tengah dan Belakang.

3. Membuat rating kecocokan pada setiap kriteria pada setiap alternative

Proses menentukan rating kecocokan, dimulai dari mendefenisikan atribut yang menjadi alternatif dalam pengambilan keputusan. Selanjutnya dibuat suatu tingkat kepentingan kriteria berdasarkan nilai bobot yang telah ditentukan ke dalam bilangan fuzzy dan disimbolkan dengan $(\mathbf{W})$. dengan persamaan yaitu: 


$$
W_{n}=\frac{W_{j}}{\sum W_{J}}
$$

dimana Wn menyatakan nilai rating kecocokan untuk Kriteria ke-n, yang didapat dari hasil bagi terhadap urutan Kriteria Ke-n (Wj) dengan Jumlah Keseluruhan dari Kriteria (Ewj). Setelah didapatkan nilai rating kecocokan pada setiap kriteria akan ditentukan nilai bobotnya yang terdiri dari 3 atribut fuzzy, yaitu Rendah(R), Optimum(O) dan Berlebihan (B)

4. Membuat matrik keputusan berdasarkan Kriteria $\mathrm{C}$

Setelah diketahui nilai rating kecocokan dan bobot dari setiap kriteria, selanjutnya dibuat matrik keputusan dengan cara mengubah data hasil konversi nilai bobot pada setiap alternatif berdasarkan nilai bobot masing-masing kriteria (C).

5. Melakukan normalisasi matriks berdasarkan persamaan yang disesuaikan dengan jenis atribut, sehingga diperoleh matrik ternormalisasi (R). Selanjutnya dilakukan proses normalisasi matriks berdasarkan persamaan yang disesuaikan dengan jenis atribut sehingga diperoleh matriks ternormalisasi $\mathrm{R}$ dengan persamaan berikut:

$$
\text { Matriks } X_{i j}=\left\{\begin{array}{lllll}
X_{11} & X_{12} & \ldots & \ldots & X_{1 n} \\
X_{21} & X_{22} & \ldots & \ldots & X_{2 n} \\
X_{31} & X_{32} & \ldots & \ldots & X_{3 n}
\end{array}\right\}
$$

Setelah matrik keputusan terbentuk, selanjutnya melakukan normalisasi terhadap matrik keputusan dengan menggunakan persamaan berikut:

$$
R i j=\left\{\begin{array}{l}
\frac{X i j}{\operatorname{Max}(X i j)} \\
\frac{X i j}{\operatorname{Min}(X i j)}
\end{array}\right.
$$

6. Melakukan proses perankingan yaitu penjumlahan dari perkalian matriks ternormalisasi (R) dengan vektor bobot sehingga diperoleh nilai terbesar yang dipilih menjadi alternatif terbaik (A) sebagai referensi acuan yang akan digunakan dalam proses penentuan dosis pupuk. Setelah proses normalisasi dilakukan atau matrik ternormalisasi sudah didapatkan, tahap terakhir untuk mendapatkan proses perangkingan $(\mathrm{Vi})$ yaitu dengan cara mengalihkan bobot (W) pada setiap kriteria yang sudah ditentukan dengan matrik yang telah ternormalisasi (R) dengan menggunakan persamaan berikut:

$$
V i=(R i j * w n)
$$

Berdasarkan data hasil perhitungan bobot preferensi, selanjutnya dilakukan proses perangkingan terhadap hasil perhitungan untuk mendapatkan alternatif terbaik.

7. Melakukan proses perhitungan perbandingan terhadap alternatif terpilih yang akan menghasilkan sebuah rekomendasi dosis pupuk POC NASA pada tanaman kelapa sawit. Setelah alternatif telah didapatkan, selanjutnya melakukan proses perbandingan terhadap jumlah komposisi yang ada pada pupuk organic cair (POC) NASA terhadap jumlah kandungan unsur yang ada pada setiap kriteria pada alternatif terpilih yaitu:

- Konversi setiap Kiteria pada alternatif terpilih dengan Kemasan POC NASA

- Bandingkan hasil konversi dengan jumlah Komposi Setiap kriteria di setiap Volume POC NASA

\subsection{Pengumpulan Data}

Data yang digunakan dalam penelitian ini di dapat dari hasil penelitian laboratorium yang dikeluarkan oleh Asosiasi SAMADE Wilayah Riau yang sebelumnya di dapat dari penelitian langsung pada perkebunan kelapa sawit masyarakat, seperti : data pertumbuhan tanaman kelapa sawit, data pengujian contoh daun dan pelepah kelapa sawit, serta data pengujian contoh tanah. 


\subsection{Konsep Teori}

\subsubsection{Simple Additive Weighting (SAW)}

SAW merupakan metode yang menggunakan teknik atau cara penjumlahan terbobot, dasar konsep SAW dimulai dari mencari hasil jumlah terbobot dari proses rating kinerja yang ada pada tiap alternatif pada semua atribut [11]. Metode SAW membutuhkan proses normalisasi matriks keputusan (X) ke suatu skala yang dapat diperbandingkan dengan semua rating alternatif yang ada [12]. Kelebihan SAW dibandingkan dengan pemodelan yang sama adalah terletak pada kesanggupan dalam melakukan penilaian lebih tepat, karena berdasarkan pada nilai $\mathrm{C}$ dan bobot yang telah ditetapkan, selain itu SAW juga mampu memilih $\mathrm{V}_{i}$, (alternatif) yang paling baik dari daftar $\mathrm{V}_{i,}$ yang ada karena adanya pengaruh dari proses perankingan setelah menentukan nilai bobot untuk setiap atribut.

\subsubsection{Kelapa Sawit}

Kelapa sawit (Elaeis guineensis Jacq.) merupakan komoditi unggul dari perkebunan yang dikategorikan penting di Indonesia sebagai sumber penyokong pendapatan negara. Indonesia saat ini adalah produsen minyak sawit dari asean yang terbesar di dunia dari negara lainnya [13]. Minyak nabati merupakan hasil dari tanaman sawit yang sampai sekarang memiliki keunggulan yang lebih jika dibandingkan dengan tanaman lain yang menghasilkan produk yang sama yaitu produktivitas yang tinggi mencapai \pm 4 ton ha-1 Crude Palm Oil (CPO), serta disisi umur tanaman yang ekonomis dan panjang serta mudah beradaptasi dengan lingkungan tanaman. Produk minyak sawit juga dimanfaatkan sebagai bahan baku pembuatan bahan pangan maupun non pangan, dan bahan bakar yang renewable.

\subsubsection{Android}

Android merupakan salah satu sistem operasi mobile open source yang memungkinkan pengguna dapat mengembangkan aplikasi yang akan dijalan diatas sistem operasi android [14]. Sehingga banyak para pengguna lebih menggunakan sistem operasi android dalam mengembangkan aplikasi dan dapat digunakan secara mudah dan portable. Aplikasi yang dibangun dalam penelitian ini, merupakan aplikasi yang dikembangkan untuk dijalankan di android untuk membantu para pengguna atau petani dalam hal pemberian dosis pemupukan (POC) NASA yang tepat terhadap tanaman kelapa sawit.

\section{HASIL DAN PEMBAHASAN}

Hasil dari penelitian ini adalah berupa sistem aplikasi Penentuan Pemupukan Kelapa sawit menggunakan metode SAW berbasis Android. Dimana aplikasi ini dibagi menjadi dua jenis, aplikasi pertama adalah aplikasi berbasis desktop yang digunakan untuk mengelola data pendukung yang diperlukan dalam proses Penentuan Rekomendasi. Sementara aplikasi berikutnya adalah Aplikasi berbasis android untuk keperluan proses menentukan hasil rekomendasi pemupukan POC Terhadap Kelapa sawit. Dalam proses pengujian aplikasi yang dilakukan oleh user dalam menentukan rekomendasi pupuk mampu menampilkan data rekomendasi berdasarkan data sampel tanah, daun dan pelepah. Dari aplikasi yang dibangun juga dilakukan penilaian kuisioner dari sampel 90 orang petani yang tergabung dalam kelompok tani agro lestari, terhadap sistem yang di buat, dan di dapat tingkat kepuasan user sebesar $82,4 \%$ jadi aplikasi yang dibangun berbasis android dapat memberikan hasil yang sangat baik dalam memberikan rekomendasi jumlah dosis pupuk POC NASA yang tepat terhadap tanaman kelapa sawit.

\subsection{Halaman Aplikasi Desktop}

Aplikasi berbasis desktop merupakan aplikasi yang dibangun untuk mengelola seluruh data pendukung yang diperlukan dalam proses penentuan dosis pemupukan. Pada aplikasi ini terdapat menu antara lain: Data rekap uji data sampel kebun, manajemen data Kriteria dan bobot, manajemen data bobot Preferensi, manajemen data matrik keputusan. Untuk hierarki sistem aplikasi pengelolaan data pendukung pemupukan, seperti terlihat pada gambar 7-10 berikut. 


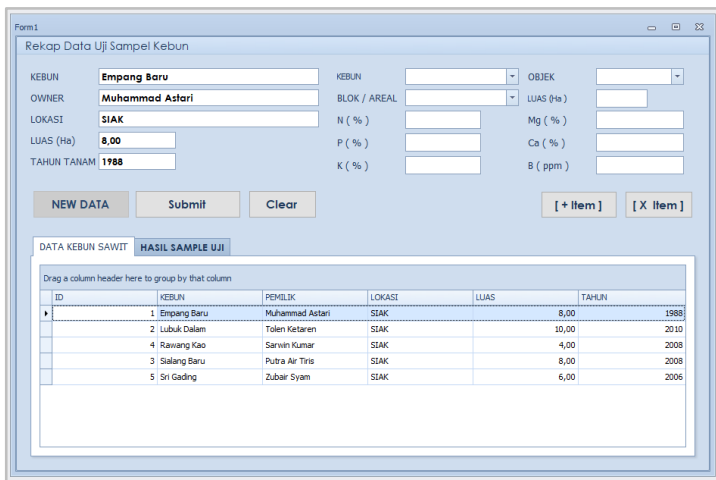

Gambar 7. Rekap data uji sampel kebun

\begin{tabular}{|c|c|c|c|c|c|c|}
\hline \multicolumn{7}{|c|}{ 唱 PROGRESS SAW } \\
\hline \multicolumn{7}{|c|}{ PILIH KEBUN } \\
\hline \multicolumn{2}{|c|}{ EASTATE } & \multicolumn{3}{|c|}{ Empang Baru } & $\checkmark$ & GENERATI \\
\hline \multicolumn{2}{|c|}{ DATA SAMPEL } & \multicolumn{2}{|c|}{ KRITERIA \& BOBOT BC } & \multicolumn{2}{|c|}{ BOBOT PREFERENSI ( W ) } & MATRIKS KEPU \\
\hline & KRITERIA & & PREFERENSI ( $W$ ) & & NILAI BOBOT $(W)$ & \\
\hline 1 & B & & $1 /(6-1)$ & & 0.2 & \\
\hline 2 & $\mathrm{Ca}$ & & $2 /(6-1)$ & & 0.4 & \\
\hline 3 & $\mathrm{Mg}$ & & $3 /(6-1)$ & & 0.6 & \\
\hline 4 & $\mathrm{k}$ & & $4 /(6-1)$ & & 0.8 & \\
\hline 5 & $\mathrm{P}$ & & $5 /(6-1)$ & & 1 & \\
\hline 6 & $\mathrm{~N}$ & & $6 /(6-1)$ & & 1.2 & \\
\hline & & & & & & \\
\hline
\end{tabular}

Gambar 9. Bobot Preferensi

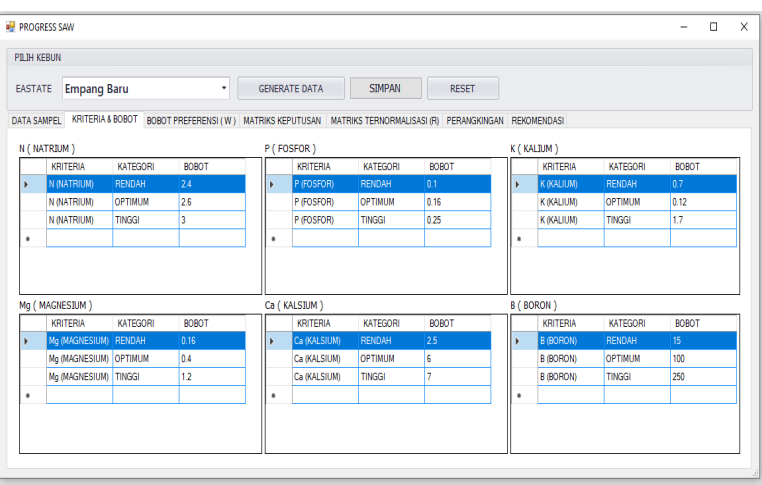

Gambar 8. Tampilan Kriteria dan Bobot

\begin{tabular}{|l|l|l|l|l|l|l|l|}
\hline PILIH KEBUN & \\
\hline
\end{tabular}

Gambar 10. Matrik Keputusan

\subsection{Halaman Aplikasi Android}

Proses utama untuk memulai penggunaan Aplikasi rekomendasi Menggunakan metode SAW Berbasis Android ini yaitu dengan mengklik menu Login, yang membutuhkan username dan password pengguna, seperti terlihat pada gambar 11.

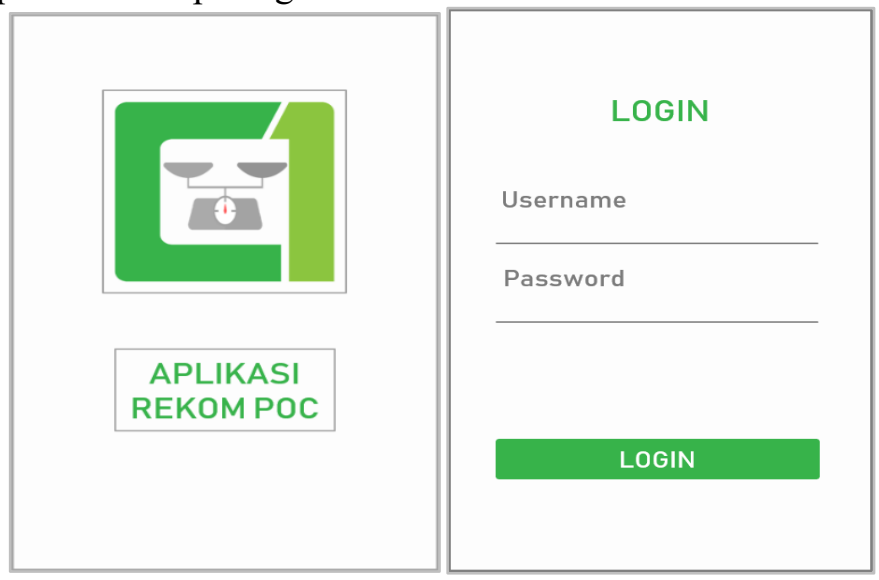

Gambar 10. Menu Login

Setelah berhasil Login akan masuk ke Menu Pilihan data terlihat pada gambar 11. 


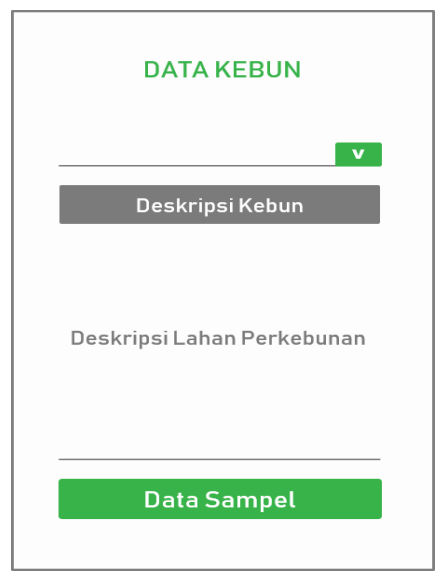

Gambar 11. Datfar Kebun

Kemudian proses penentuan rekomendasi dapat dilakukan setelah memilih data kebun dan selanjutnya aplikasi akan menampilkan data sampel kebun. Setelah itu, aplikasi mengolah data sampel menggunakan metode SAW untuk mendapatkan hasil rekomendasi pupuk sesuai dengan data sampel yang ada seperti terlihat pada gambar 12 .

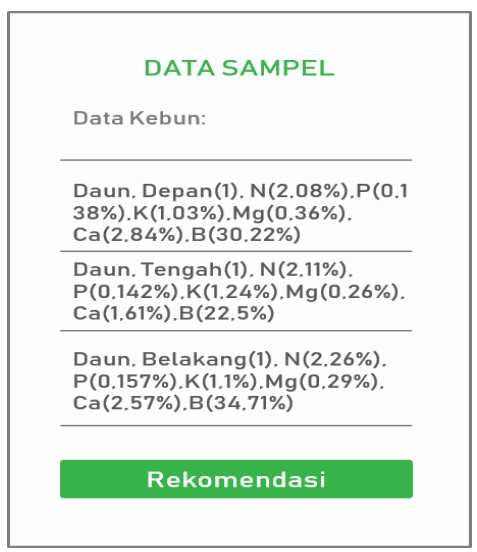

Gambar 12. Data sampel Kebun

\begin{tabular}{|c|c|c|}
\hline PROSES REKOMENDASI & HASIL PERANGKINGAN & HASIL REKOMENDASI \\
\hline Kriteria & Sampel Kebun & Data Sampel Terpilih \\
\hline $\begin{array}{l}\mathrm{N} \text { - Nitrogen } \\
\text { Rendah }-2.4 \\
\text { Optimum }-2.6 \\
\text { Tinggi }-3\end{array}$ & \multirow{3}{*}{$\begin{array}{l}\mathrm{N}-2,51 \\
\mathrm{P}-0,165 \\
\mathrm{~K}-1,2 \\
\mathrm{Mg}-0,35 \\
\mathrm{Ca}-3,2 \\
\mathrm{~B}-24,22 \\
\text { Nilai }-4\end{array}$} & $\begin{array}{l}\text { Kebun:Empang Baru. Luas } 4 \mathrm{Ha} \text {. } \\
\text { Tanah. Tengah(2). } \mathrm{N}(2.15) . \mathrm{P}(0.16 \\
\text { 5).K(1.2) Mg(0.35). } \mathrm{Ca}(3.21) . \\
\mathrm{B}(24.22)\end{array}$ \\
\hline \multirow{2}{*}{$\begin{array}{l}P \text { - Fosfor } \\
\text { Rendah }-2,4 \\
\text { Optimum }-2.6 \\
\text { Tinggi - } 3\end{array}$} & & Rekomendasi POC \\
\hline & & $\begin{array}{l}\text { Luas Lahan: } 4 \text { ha } \\
\text { POC }-250 \mathrm{ml} \\
\text { Rekomendasi (Botol) }-17.9\end{array}$ \\
\hline $\begin{array}{l}\text { K - Kalium } \\
\text { Rendah - 2,4 } \\
\text { Optimum - 2,6 } \\
\text { Tinggi - } 3\end{array}$ & \multirow{2}{*}{$\begin{array}{l}\text { Volume }-250 r \\
\mathrm{~N}-0.3 \\
\mathrm{P}-0.75 \\
\mathrm{~K}-0,775 \\
\mathrm{Mg}-42,22 \\
\mathrm{Ca}-151,00 \\
\mathrm{~B}-152,00\end{array}$} & \multirow{2}{*}{$\begin{array}{l}\text { Rekomendasi / Ha } \\
\text { POC }-250 \mathrm{ml} \\
\text { Rekomendasi (Botol) }-4.48 \\
\text { MAIN MENU }\end{array}$} \\
\hline & & \\
\hline
\end{tabular}

(a)

(b)

Gambar 13 (a) Tampilan Datftar kriteria \& bobot,(b) data Perangkingan,

(c) hasil Rekomendasi dosis POC 


\section{KESIMPULAN}

Penelitian ini telah berhasil dilakukan dan memberikan beberapa kesimpulan yaitu :

1. Aplikasi yang dibangun mampu mengatasi persoalan-persoalan dalam proses penentuan rekomendasi dosis POC NASA pada tanaman kelapa sawit secara praktis karena berbasis android dengan mengimplementasikan metode SAW. Dan dari aplikasi yang dibangun telah dilakukan penilaian kuisioner dari sampel 90 orang petani yang tergabung dalam kelompok tani agro lestari, dan di dapat tingkat kepuasan user sebesar $82,4 \%$ jadi aplikasi yang dibangun berbasis android dapat memberikan hasil yang sangat baik dalam memberikan rekomendasi jumlah dosis pupuk POC NASA yang tepat terhadap tanaman kelapa sawit.

2. Hasil penelitian ini telah menghasilkan suatu rekomendasi yang dapat dimanfaatkan untuk mengambil kebijakan dalam menggunakan pupuk POC NASA kemasan $250 \mathrm{ml}$ dengan dosis pemupukan yang direkomendasikan sebanyak 21 botol untuk area lahan $2 \mathrm{Ha}$ atau 11 bobot POC NASA kemasan $250 \mathrm{ml}$ untuk per-hektarnya, dimana luas lahan didapat berdasarkan pada alternatif yang dipilih.

\section{UCAPAN TERIMA KASIH}

Penulis mengucapkan terima kasih yang sebesarnya kepada Kementerian Riset dan Teknologi Pendidikan Tinggi (KEMENRISTEK DIKTI) yang telah memberikan dukungan Finansial terhadap penelitian ini sehingga penelitian ini dapat terlaksana dengan baik.

\section{DAFTAR PUSTAKA}

[1] Rafflegeau, S., Michel-Dounias, I., Tailliez, B., Ndigui, B., \& Papy, F. (2010). Unexpected N and $\mathrm{K}$ nutrition diagnosis in oil palm smallholdings using references of high-yielding industrial plantations. Agronomy for Sustainable Development, 30(4), 777-787.

[2] Dody, Jayadi \& Wahyu. 2011, "Analisa dan Perancangan Aplikasi Wisata dengan Menggunakan Teknologi QR Code pada Platform Android", Binus University, Jakarta.

[3] Paramananthan, S. (2013). Managing marginal soils for sustainable growth of oil palms in the tropics. Journal of Oil Palm, Environment and Health (JOPEH), 4.

[4] Suharta, N. (2017). Karakteristik dan permasalahan tanah marginal dari batuan sedimen masam di Kalimantan. Jurnal Penelitian dan Pengembangan Pertanian, 29(4), 139-146.

[5] Obi, J. C., \& Udoh, B. T. (2012). Nutrient budget for optimal oil palm (Elaeis guineensis Jacq) yield on coastal plain sands soils of Akwa Ibom State Nigeria. Open Journal of Soil Science, 2(03), 289.

[6] Neli, S., Jannah, N., \& Rahmi, A. (2016). Pengaruh Pupuk Organik Cair Nasa dan Zat Pengatur Tumbuh Ratu Biogen Terhadap Pertumbuhan dan Hasil Tanaman Terung (Solanum melongena L.) Varietas Antaboga-1. Agrifor, 15(2), 297-308.

[7] Irfanda, M., \& Santosa, E. (2016). Peramalan Produksi Kelapa Sawit (Elaeis guineensis Jacq.) di Perkebunan Sei Air Hitam berdasarkan Kajian Faktor Agroekologi. Buletin Agrohorti, 4(3), 282-287.

[8] Qorry, O. (2018). Kelimpahan dan pola aktivitas kijang (muntiacus muntjak, zimmermann 1780) di kawasan hutan konservasi prof. Dr. Sumitro djojohadikusumo pt. Tidar kerinci agung (tka) (Doctoral dissertation, Universitas Andalas).

[9] A. Reski Amelia Hidayah " Pemupukan dan Penentuan Dosis Pupuk Spesifik Lokasi Pada Plasma Perkebunan Kelapa Sawit di Perkebunan PT Unit Perkebunan XIV Luwu Timur (Burau), 2017.

[10] Alvi, B., Ariyanti, M., \& Maxiselly, Y. (2018). Pemanfaatan beberapa jenis urin ternak sebagai pupuk organik cair dengan konsentrasi yang berbeda pada tanaman kelapa sawit (Elaeis guineensis jacq.) di pembibitan utama. Kultivasi, 17(2), 622-627.

[11] Sudrajat., Fitriya., (2015), "Optimasi Dosis pupuk dolomit pada tanaman kelapa sawit (Elaesis Guinneensis Jacq.) belum menghasilkan umur satu tahun.” Jurnal Agrovigor Vol.8 No.1. 
[12] Ruskan, E. L., Ibrahim, A., \& Hartini, D. C. (2013). Sistem Pendukung Keputusan Pemilihan Hotel Di Kota Palembang Dengan Metode Simple Additive Weighting (SAW). JSI: Jurnal Sistem Informasi (E-Journal), 5(1).

[13] Ristyawan, A., \& Indriyono, B. V. (2015). Penerapan Metode Simple Additive Weighting (Saw) Untuk Pengambilan Keputusan Pemberian Upah Karyawan. SEMNASTEKNOMEDIA ONLINE, 3(1), 1-2.

[14] Dewi, N. K. C., Anandita, I. B. G., Atmaja, K. J., \& Aditama, P. W. (2018). RANCANG BANGUN APLIKASI MOBILE SISKA BERBASIS ANDROID. SINTECH (Science and Information Technology) Journal, 1(2), 100-107.

[15] Song, I. Y., \& Froehlich, K. (1994). Entity-relationship modeling. IEEE Potentials, 13(5), 2934.

[16] Elistri, M., Wahyudi, J., \& Supardi, R. (2014). Penerapan metode saw dalam sistem pendukung keputusan pemilihan jurusan pada Sekolah Menengah Atas Negeri 8 Seluma. Jurnal Media Infotama, 10(2).

\section{BIOGRAFI PENULIS}

\begin{tabular}{|l|l|}
\hline & $\begin{array}{l}\text { Fitri Ayu Received the Bachelor of Computer Science in 2009 and Master of Information } \\
\text { Technology in } 2011 \text { from Universitas Putra Indonesia "YPTK" (UPI "YPTK" Padang) Currently, } \\
\text { she has been Lecturer in College of AMIK Mhaputra Riau, the Faculty of Information Engineering } \\
\text { of Riau University, and also an Assistant in An-Namiroh Education Foundation, Pekanbaru since } \\
\text { 2012. Her current research interest are Programming and Android Applications making. }\end{array}$ \\
\hline & $\begin{array}{l}\text { Ari Mustofa Received the Bachelor of engineering from Institut Teknologi Medan in } 2009 \text { and } \\
\text { Master of Information Technology in 2018 from Universitas Putra Indonesia "YPTK" (UPI } \\
\text { "YPTK" Padang) Currently, she has been a Lecturer in College of AMIK Mahaputra Riau, } \\
\text { Research that is of interest right now is programming and making desktop and Android based } \\
\text { applications. }\end{array}$ \\
\hline
\end{tabular}

